\title{
Case Study on Power Quality Improvement of Thirty Bus System with UPFC
}

\author{
P.Kannan ${ }^{1}$ and S. Chenthur Pandian ${ }^{2}$
}

\begin{abstract}
The unified power flow controller (UPFC) is a pair of back to back power electronic inverters which controls the real and reactive power flow in a transmission line. This paper describes the modeling and simulation of IEEE 30 bus system employing UPFC. Simulink models are developed for IEEE 30 bus system with and without UPFC. Digital simulation using MATLAB/SIMULINK is done with these models and the results are presented. The effect of UPFC on real power, reactive power and the voltage is also presented.
\end{abstract}

Index Terms-FACTS, UPFC, Power Quality, MATLAB, SIMULINK

\section{INTRODUCTION}

The flexible AC transmission systems (FACTS) concept based on applying leading edge Power Electronics Technology to existing AC transmission systems, improves stability to increase usable power transmission capacity to its thermal limit. A UPFC can simultaneously provide control of the transmission line impedance, phase angle and reactive power [1].

The UPFC is constructed from two power electronic inverters which are connected together by a common DC link as shown in Fig.1. Two transformers are used to isolate the UPFC and to match the voltage levels between the power system and the power electronic inverters. One of the inverter is connected to the transmission line. The series connected inverter can generate a voltage which can have adjustable magnitude and phase angle. This inverter therefore can provide both real and reactive power to the transmission line. The second inverter primarily provides the real power required by the series inverter but it can also operate as an independent VAR compensator. Therefore the UPFC can control the flow of real and reactive power in the transmission line [1]-[2].

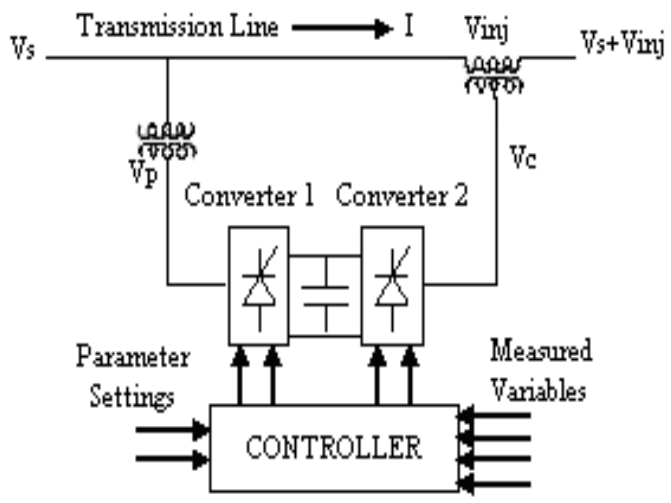

Fig.1 Basic power system with UPFC

Fig.1 Basic power system with UPFC

Manuscript received September 19, 2010; revised May 6, 2011.
The two VSI's can work independently of each other by separating the DC side. So in that case, the shunt inverter is operating as a STATCOM that generates or absorbs reactive power to regulate the voltage magnitude at the connecting point. The series inverter is operating as SSSC that generates or absorbs reactive power to regulate the current flow, and hence the power flow on the transmission line [3].

\section{UPFC CONTROL STRATEGY}

\section{A. Shunt Inverter}

The UPFC has several operating modes. The shunt inverter is operated in such a way as to draw a controlled current from the AC bus. The current reference is chosen to satisfy the shunt reactive power reference and to provide any real power needed to balance the real power of the series inverter. The shunt reactive power reference can be either capacitive or inductive.

VAR Control Mode: The reference input is a simple var request that is maintained by the control system regardless of bus voltage variation.

The real and reactive power equations are as follows:

$$
\begin{gathered}
P=\frac{V_{1} V_{2}}{X} \sin \left(\delta_{1}-\delta_{2}\right) \\
Q=\frac{V_{2}}{X}\left(V_{1}-V_{2}\right)
\end{gathered}
$$

Automatic Voltage Control Mode: The shunt inverter reactive current is automatically regulated to maintain the transmission line voltage at the point of connection to a reference value with a defined slope characteristics. The slope factor defines the per unit voltage error per unit of inverter reactive current within the current range of the inverter.

\section{B. Series Inverter}

The series inverter controls the magnitude and angle of the voltage injected in series with the line. This voltage injection is always intended to influence the flow of power on the line. The series voltage can be determined in different ways.

Phase Angle Shifter Emulation Mode: The reference input is phase displacement between the sending and voltage and the receiving end voltage.

Line Impedance Emulation Mode: The reference input is an impedance value to insert in series with the line impedance.

Automatic Power Flow Control Mode: The reference inputs are values of $\mathrm{P}$ and $\mathrm{Q}$ to maintain on the transmission line despite system changes. 
In general the shunt inverter will be operated in automatic voltage control mode and the series inverter in automatic power flow control mode. [4]-[9]

The above literature does not deal with the simulink modeling of thirty bus system using UPFC controller. This paper presents modeling and simulation of thirty bus system using matlab/simulink.

\section{SimUlation RESUlts}

The IEEE 30 bus system is modeled using matlab and it is simulated using the blocks of simulink. Each line is represented by the respective impedance. The generators in the network are represented as voltage sources. The load at the load bus is represented as series combination of $\mathrm{R}$ and $\mathrm{L}$. The simulink model of IEEE 30 bus system is shown in Fig. 2. The voltage of bus 11 is shown in Fig. 3. Real and reactive powers at bus 11 are shown in Figures 4 and 5. The matlab simulink model of IEEE thirty bus system with two unified power flow controllers is shown in Fig.6. The UPFC 1 is connected between bus 2 and bus 11. The second UPFC is connected between the buses 9 and 27. The voltage at bus 11 is shown in Fig. 7. The real and reactive powers at bus 11 are shown in Figures 8 and 9 respectively. The summary of real power, reactive power and bus voltages with and without UPFC are given in Fig.10. The buses nearer to the UPFC systems are considered. It can be seen that the real power, reactive power and bus voltage increase by $3 \%$ by adding UPFC systems. The variation of reactive power with the variation in the injected voltage is given in Fig.11. The buses $11,13,19,21,25$ and 26 are considered since they are nearer to the UPFC. The reactive power increases with the increase in the value of injected voltage. The summary of bus voltages with an injected voltage of $11 \mathrm{KV}$ is given in Fig. 12.

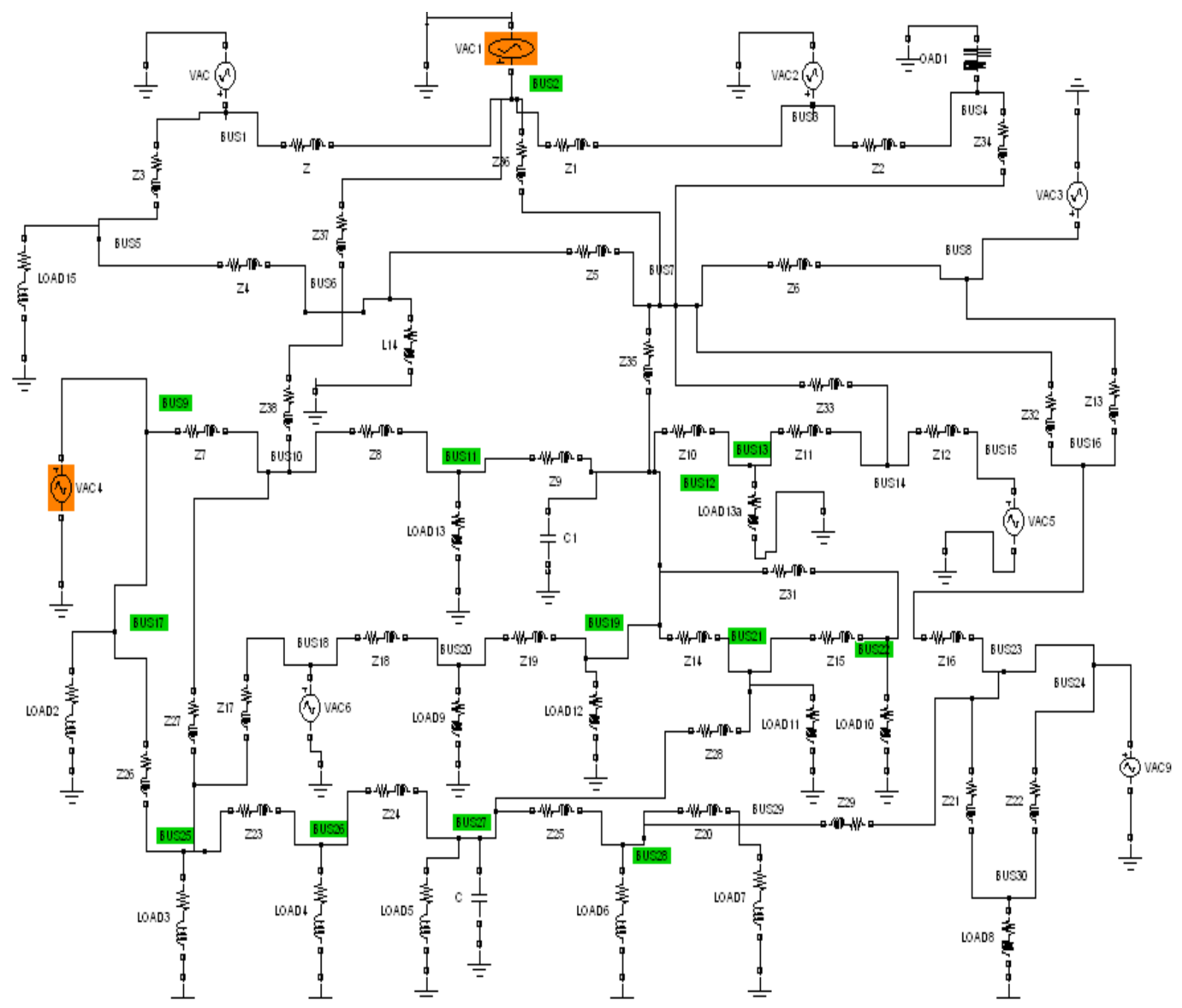

Fig.2. Simulink Model of IEEE 30 Bus Systems 


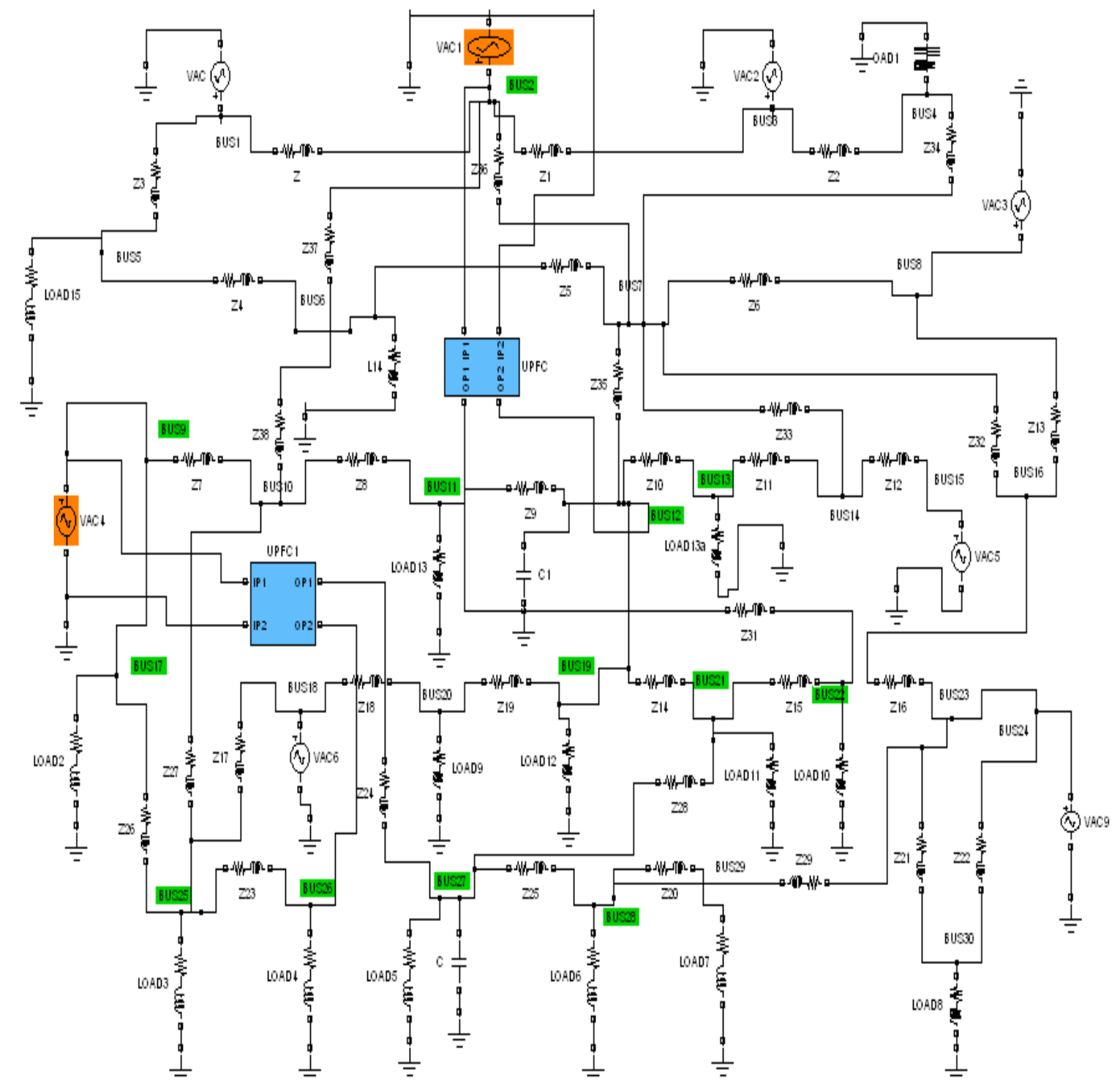

Fig. 6. Simulink Model of IEEE 30 Bus System with UPFC

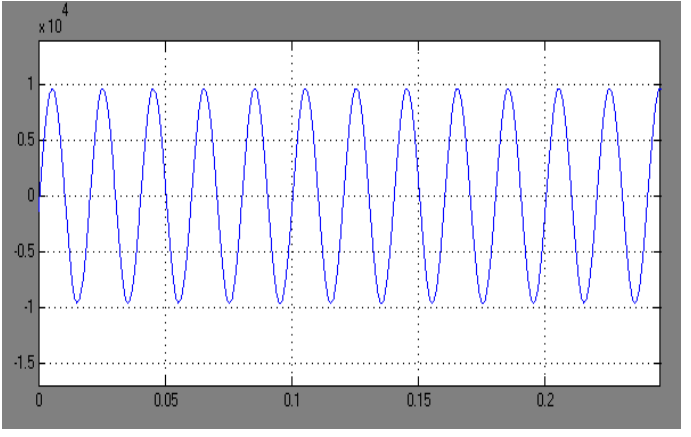

Fig. 3. Voltage across Bus 11

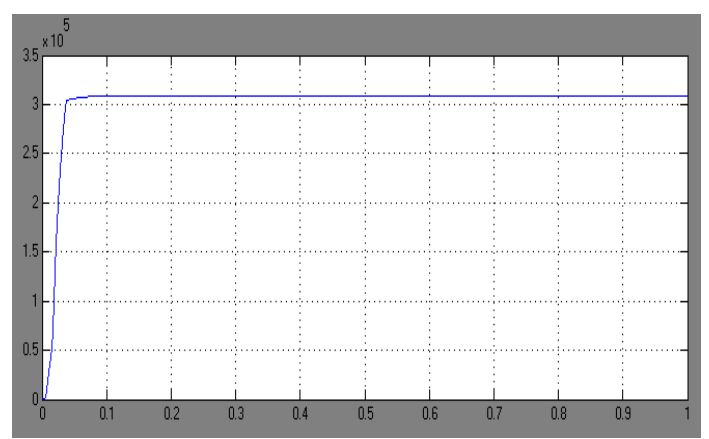

Fig. 4. Real Power at Bus 11

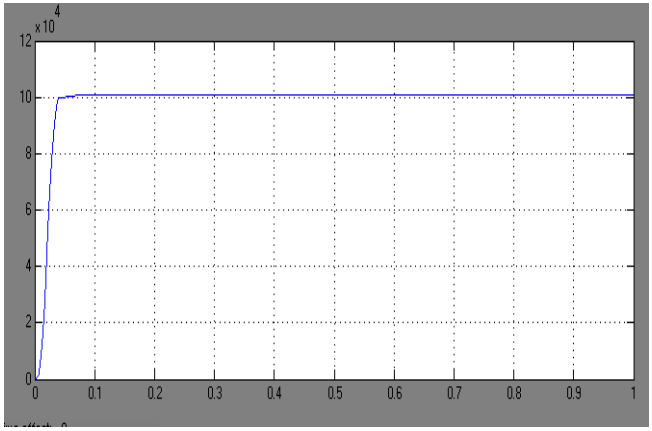

Fig. 5. Reactive Power at Bus 11

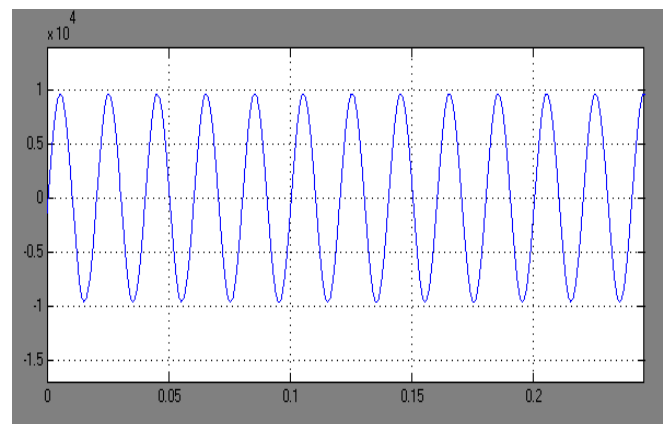

Fig. 7. Voltage across Bus 11 


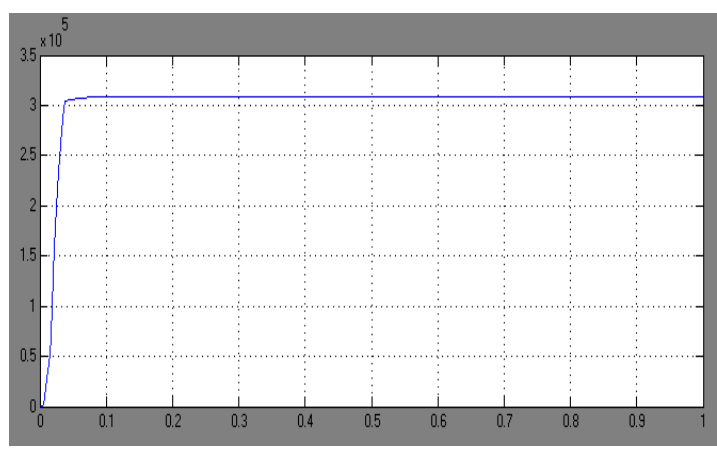

Fig. 8. Real Power at Bus 11

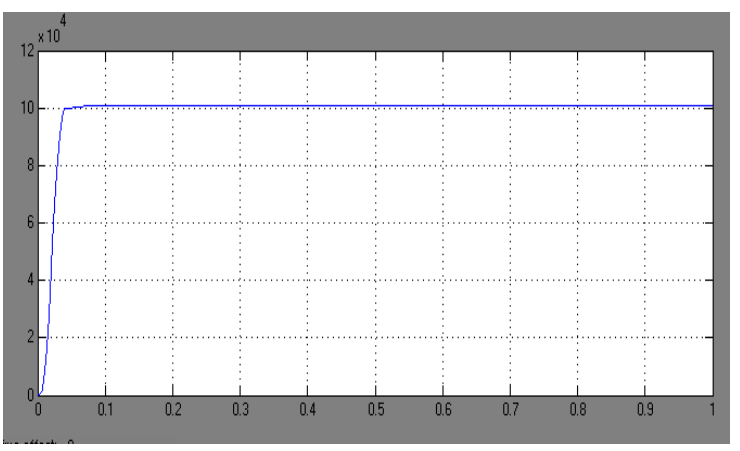

Fig.9. Reactive Power at Bus 11

\begin{tabular}{|c|c|c|c|c|c|c|}
\hline $\begin{array}{c}\text { Bus } \\
\text { no }\end{array}$ & $\begin{array}{c}\mathrm{P} \\
\text { (MW) } \\
\text { withou } \\
\text { t UPFC }\end{array}$ & $\begin{array}{c}\mathrm{P} \\
\text { (MW) } \\
\text { with } \\
\text { UPFC }\end{array}$ & $\begin{array}{c}\mathrm{Q} \\
\text { (MVAR) } \\
\text { without } \\
\text { UPFC }\end{array}$ & $\begin{array}{c}\mathrm{Q} \\
\text { (MVAR) } \\
\text { with } \\
\text { UPFC }\end{array}$ & $\begin{array}{c}\text { VOLTAGE } \\
\text { (V) without } \\
\text { UPFC (RMS) }\end{array}$ & $\begin{array}{c}\text { VOLTAGE } \\
\text { (V) with } \\
\text { UPFC } \\
\text { (RMS) }\end{array}$ \\
\hline 11 & 0.418 & 0.421 & 0.131 & 0.132 & 6783 & 6798 \\
\hline 13 & 0.338 & 0.340 & 1.065 & 1.067 & 6069 & 6075 \\
\hline 19 & 0.341 & 0.346 & 0.134 & 0.136 & 6868 & 6876 \\
\hline 21 & 0.286 & 0.304 & 0.0934 & 0.0991 & 6295 & 6479 \\
\hline 25 & 0.390 & 0.394 & 1.229 & 1.238 & 6520 & 6545 \\
\hline 26 & 0.273 & 0.283 & 0.857 & 0.889 & 5448 & 5548 \\
\hline
\end{tabular}

Fig.10. Summary of $P, Q \& V$

\begin{tabular}{|c|c|c|c|c|c|c|}
\hline $\begin{array}{c}\text { INJECTE } \\
\text { D } \\
\begin{array}{c}\text { VoLTAG } \\
\text { (KV) }\end{array}\end{array}$ & $\begin{array}{c}\text { BUS 11 } \\
\text { Q(MV } \\
\text { AR) }\end{array}$ & $\begin{array}{c}\text { BUS 13 } \\
\text { (MV } \\
\text { AR) }\end{array}$ & $\begin{array}{c}\text { BUS 19 } \\
\text { (MVAR } \\
\text { ) }\end{array}$ & $\begin{array}{c}\text { BUS 21 } \\
\text { Q(MVAR } \\
\text { ) }\end{array}$ & $\begin{array}{c}\text { BUS 25 } \\
\text { Q(MV } \\
\text { AR) }\end{array}$ & $\begin{array}{c}\text { BUS 26 } \\
\text { (MVAR) }\end{array}$ \\
\hline 11 & 0.131 & 1.065 & 0.134 & 0.0934 & 1.229 & 0.857 \\
\hline 22 & 0.293 & 1.67 & 0.234 & 0.1729 & 2.835 & 1.662 \\
\hline 33 & 0.517 & 2.418 & 0.361 & 0.867 & 5.08 & 2.67 \\
\hline
\end{tabular}

Fig.11. Variation of Q with Injected Voltage

\begin{tabular}{|c|c|c|c|c|c|c|}
\hline $\begin{array}{c}\text { INJECTED } \\
\text { VOLTAGE } \\
\text { (KV) }\end{array}$ & $\begin{array}{c}\text { BUS 11 } \\
\text { voltage }\end{array}$ & $\begin{array}{l}\text { BUS 13 } \\
\text { voltage }\end{array}$ & $\begin{array}{l}\text { BUS 19 } \\
\text { voltage }\end{array}$ & $\begin{array}{l}\text { BUS 21 } \\
\text { voltage }\end{array}$ & $\begin{array}{c}\text { BUS 25 } \\
\text { voltage }\end{array}$ & $\begin{array}{c}\text { BUS 26 } \\
\text { voltage }\end{array}$ \\
\hline 11 & 6790 & 6075 & 6876 & 6479 & 6545 & 5548 \\
\hline
\end{tabular}

Fig.12 . Summary of Bus Voltages

\section{CONCLUSION}

The IEEE 30 bus system is modeled and simulated with and without UPFC. Voltage quality is improved by using voltage source injection. The simulation is done successfully with the models developed. It is observed that the real power increases with the increase in the angle of injection and the reactive power increases with the increase in the magnitude of shunt voltage. Variation of reactive power with the variation in the injected voltage is presented. The simulation results are inline with the predictions.

\section{REFERENCES}

[1] L. Gyugyi, C.D. Schauder, S.L. Williams, T.R.Reitman, D.R. Torgerson and A.Edris, "The unified power flow controller: A new approach to power transmission control", IEEE Transaction Power Delivery, Vol.10, pp. 1085-1097, Apr.1995.

[2] S.D. Round, Q. Yu, L.E. Norum and T.M. Undeland, "Performance of a unified power flow controller using D-Q control system", IEE conference publication no.423 on AC and DC power transmission, pp.357-362, May 1996.

[3] M.Toufan, U.D.Annakkage, "Simulation of the unified power flow controller performance using PSCAD/EMTDC", Electric power systems research 46, pp. 67-75, January 1998.

[4] K.R. Padiyar and A.M. Kulkarni, "Control design and simulations of unified power flow controller", IEEE Transaction Power Delivery, Vol. 13, pp 1348-1354, Oct.1998.

[5] S.D. Round, Q. Yu, L.E. Norum and T.M. Undeland, "Dynamic control of a unified power flow controller", proceedings of IEEE conference, pp 508-514, 1996

[6] Samina Elyas, R.K. Nema and Gayatri Agnihotri "Power Flow Control with UPFC in Power Transmission System" World Academy of science, Engineering and Technology 47, pp338- 342, 2008.

[7] Nashiren.F. Mailah and Senan M. Bashi, "Single Phase Unified Power Flow Controller (UPFC): Simulation and Construction", European Journal of Scientific Research Vol.30 No.4, pp.677-684, 2009.

[8] K.K.Sen and E.J.Stacey, "UPFC-Unified Power Flow Controller: Theory, modeling and applications", IEEE Transaction Power Delivery, Vol.ss.13, pp 1453-1460, October 1999.

[9] D. Menniti and A. Pennarelli, "Modelling of Unified Power Flow Controller into Power Systems using P-Spice”, IPST conference, Rio de Janero, Brazil, June 24-28, 2001, Paper 205.

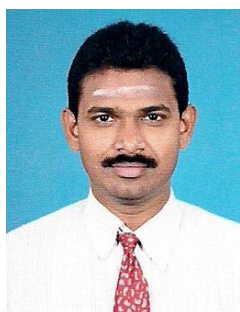

P. Kannan received his BE degree in Electrical \& Electronics Engineering from University of Madras in 1996, ME degree in Power Electronics \& Drives from Bharathidasan University in 2001. Presently he is a researchscholar at Anna University of Technology, Coimbatore, Tamilnadu, India. His areas of interest include Flexible AC Transmission Systems and Artificial Intelligence Control Techniques. He is the Life member of Indian society for Technical Education.

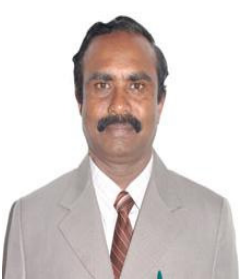

S. Chenthur Pandian received his ME degree in Power Systems from Punjab University, Chandigarh (India), Ph.D degree in fuzzy application for Power Systems from Periyar University, Salem, India. Presently he is working as Principal, Dr. Mahalingam College of Engineering and Technology, Pollachi. His areas of interest include Power Systems, Power Electronics \& Drives, and Fuzzy logic, Neural Networks, Neuro Fuzzy and Intelligent Technique applications. He has guided 10 research scholars. He published 20 research papers in National and referred International journals. 